\title{
Deskripsi Latar dalam Novel Hujan Karya Tere Liye dan Rancang Pembelajarannya di Sekolah Menengah Atas
}

\author{
Oleh \\ Riska Wulandari \\ Kahfie Nazaruddin \\ Bambang Riadi \\ Fakultas Keguruan dan Ilmu Pendidikan Universitas Lampung \\ e-mail : riskawulan467@gmail.com
}

\begin{abstract}
The purpose of this reseach is to describe the description of the settings in the Hujan novel by Tere Liye and design its learning in Senior High School. The results showed that the setting description in the novel uses three approaches, namely realistic, impressionistic, and according to the author behavior, and uses diction and figures of speech to describe settings. The dictions used are denotation and connotation, euphemism, genetic and specific, as well as figuratively in the form of simile, and personification. The results of this reseach designed learning as teaching material in Senior High School, in the form of Learning Implementation Plans for class XII even semester students with basic competencies 3.9 Analyze the content and language of the novel. The purpose of the learning is after students read the settings description with three approaches, students would be able to analyze the settings description correctly.
\end{abstract}

Keywords: description of the settings, novel, learning design.

\begin{abstract}
Abstrak
Tujuan penelitian ini untuk memerikan deskripsi latar dalam novel Hujan karya Tere Liye dan merancang pembelajarannya di SMA. Hasil penelitian menunjukkan bahwa deskripsi latar dalam novel tersebut menggunakan tiga pendekatan, yaitu pendekatan realistis, impresionistis, dan menurut sikap penulis, serta menggunakan diksi dan kiasan untuk mendeskripsikan latarnya. Diksi yang digunakan yaitu denotasi dan konotasi, eufemisme, genetik dan spesifik, serta kiasan berupa simile, dan personifikasi. Hasil penelitian ini dirancang pembelajarannya sebagai materi ajar di SMA, berupa Rencana Pelaksanaan Pembelajaran untuk siswa kelas XII semester genap dengan kompetensi dasar 3.9 Menganalisis isi dan kebahasaan novel. Tujuan pada pembelajaran tersebut adalah setelah siswa membaca deskripsi latar dengan tiga pendekatannya, siswa mampu menganalisis deskripsi latar dengan benar.
\end{abstract}

Kata kunci: deskripsi latar, novel, rancangan pembelajaran. 


\section{PENDAHULUAN}

Menurut Wellek dan Warren (dalam Wiyatmi, 2008: 14), salah satu batasan sastra adalah segala sesuatu yang tertulis. Secara sederhana dapat dikatakan bahwa sastra Indonesia ialah sastra berbahasa Indonesia, sedangkan hasilnya adalah sekian banyak puisi, cerita pendek, novel, roman, dan naskah drama berbahasa Indonesia.

Novel sebagai salah satu genre karya sastra dibangun oleh unsur intrinsik. Novel adalah cerita dengan suatu alur yang cukup panjang mengisi satu buku atau lebih, yang menggarap kehidupan manusia yang bersifat imajinatif (The Advanced of Current Englisht dalam Priyatni, 2010: 125). Novel itu dibangun melalui berbagai unsur intrinsiknya seperti tokoh, alur atau plot, latar, judul, sudut pandang, gaya bahasa, dan tema.

Semua unsur itu bersifat imajinatif.

Pada penelitian ini, peneliti berfokus pada unsur latar. Latar atau setting yang disebut juga sebagai landasan tumpu, menunjukkan pada pengertian tempat, hubungan waktu sejarah, dan lingkungan sosial tempat terjadinya peristiwa-peristiwa yang diceritakan (Abrams dalam Nurgiyantoro, 2015: 302). Unsur latar dibedakan ke dalam tiga unsur pokok, yaitu tempat, waktu, dan sosial. Latar tempat menunjukkan pada lokasi terjadinya peristiwaperistiwa yang diceritakan dalam sebuah karya fiksi. Latar waktu berhubungan dengan masalah "kapan" terjadinya peristiwa-peristiwa yang diceritakan dalam sebuah karya fiksi. Dan latar sosial budaya menunjuk pada hal-hal yang berhubungan dengan prilaku kehidupan sosial masyarakat di suatu tempat yang berhubungan diceritakan dalam karya fiksi (Nurgiyantoro, 2015: 314-322).

Penggambaran latar dalam sebuah novel biasanya ditulis dalam bentuk deskripsi. Deskripsi merupakan bentuk tulisan yang bertalian dengan usaha penulis untuk memberikan perincianperincian dari objek yang sedang dibicarakan. Dalam deskripsi latar novel digunakan tiga pendekatan, yaitu pendekatan realistis, pendekatan impresionistis, dan pendekatan menurut sikap penulis. Pada pendekatan yang realistis penulis berusaha agar deskripsi yang dibuatnya terhadap objek yang diamatinya itu, harus dapat dilukiskan seobjektif-objektifnya, sesuai dengan keadaan yang nyata yang dapat dilihatnya. Pendekatan secara impresionistis yaitu semacam pendekatan yang berusaha menggambarkan suatu subjektif, walaupun dikatakan bahwa ia mendeskripsikan kesan umum tentang benda itu, ia masih harus bertolak dari keadaan yang nyata. Pendekatan menurut sikap penulis terhadap objek yang dideskripsikan itu dapat mengambil salah satu sikap: masa bodoh, bersungguh-sungguh dan cermat, mengambil sikap seenaknya, atau sikap bersifat ironis (Keraf, 1982: 104-111).

Penelitian serupa sebelumnya telah dilakukan oleh Ria Anggraeni (2014) dengan judul "Deskripsi Latar dan Fungsinya dalam Novel Cinta di dalam Gelas karya Andrea Hirata dan Implikasinya pada Pembelajaran Sastra di SMA”. Kemudian penelitian oleh Shinta Wulandari (2018) dengan judul "Keberfungsian Latar dalamNovel Pingkan Melipat Jarak Karya Sapardi Djoko Damono dan Rancangan Pembelajarannya di SMA. Untuk membedakan dengan penelitian sebelumnya, peneliti hendak membatasi penelitian yang berfokus pada deskripsi latar.

Peneliti memilih salah satu novel karya Tere Liye yaitu novel Hujan untuk diteliti. Novel ini menyuguhkan setting yang futuristik dengan 
mengambil latar dunia pada tahun 2042-2050. Masa depan bumi di mata Tere Liye begitu dekat dengan kerusakan-kerusakan lingkungan. Latar tempat yang tak terbayangkan di masa depan, dipadu dengan isu-isu krisis lingkungan. Kelebihan dari novel Hujan adalah kisah cerita dalam novel ini menarik untuk disimak dan mendewasakan pikiran dan hati pembaca. Alur cerita yang mengalir serta konflik batin yang ditonjolkan dalam novel ini mampu membuat pembaca terhanyut dan ikut merasakan kejadian demi kejadian dengan seksama. Dengan latar waktu tahun 2050-an, pembaca diajak berimajinasi, membayangkan kondisi dunia masa depan, dengan berbagai teknologiteknologi canggih yang di dapat.

Kemudian dibuat rangcangan pembelajarannya. Perencanaan yang dimaksud yakni suatu cara yang memuaskan untuk membuat kegiatan dapat berjalan dengan baik, disertai dengan berbagai langkah yang antisipasif guna memperkecil kesenjangan yang terjadi sehingga kegiatan tersebut mencapai tujuan yang ditetapkan (Uno, 2008: 2). Pembelajaran sastra di sekolah menengah atas bertujuan untuk menumbuhkan rasa cinta dan kegemaran siswa terhadap sastra sehingga mampu mengasah kepekaan, penalaran, dan daya imajinasi terhadap budaya dan lingkungan sekitar. Dengan berapresiasi sastra, pengetahuan dan wawasan siswa akan bertambah; kesadaran dan kepekaan perasaan, sosial, dan religi akan terasa; penghargaan dan bangga terhadap sastra sebagai khazanah budaya dan intelektual akan muncul (Emzir dan Rohman, 2016: 255).

Tujuan yang hendak dicapai dalam penelitian ini adalah sebagai berikut; (1) Memerikan pendeskripsian deskripsi latar tempat dalam novel Hujan karya Tere Liye; (2) Memerikan pendeskripsian deskripsi latar waktu dalam novel Hujan karya Tere Liye; (3) Memerikan pendeskripsian deskripsi latar sosial dalam novel Hujan karya Tere Liye; (4) Merancang pembelajaran dari novel Hujan karya Tere Liye untuk siswa SMA.

Ruang lingkup penelitian ini dibatasi pada unsur instrinsik novel khususnya latar yang menggunakan deskripsi sebagai bahan ungkap dalam novel Hujan karya Tere Liye, serta rancangan pembelajaran di SMA dalam novel Hujan karya Tere Liye.

\section{METODE}

Metode yang digunakan dalam penelitian ini adalah metode deskriptif kualitatif. Penelitian ini menggunakan metode deskriptif kualiatif karena datadata yang terkumpul berbentuk katakata. Moleong (2005), mengemukakan bahwa penelitian kualitatif antara lain bersifat deskriptif, data yang dikumpulkan lebih banyak berupa katakata atau gambar dari pada angkaangka. Metode ini digunakan sesuai dengan tujuan penelitian ini, yakni mendeskripsikan latar dalam novel Hujan karya Tere Liye dan kelayaannya sebagai alternatif bahan ajar sastra di SMA. Data dalam penelitian ini berupa kata, frasa, kalimat, dan wacana yang menyangkut deskripsi latar dalam novel Hujan. Sumber data dalam penelitian ini adalah novel Hujan karya Tere Liye yang diterbitkan pada bulan Juli 2017 oleh PT Gramedia Pustaka Utama dengan tebal 320 halaman.

Teknik pengumpulan dan analisis data dalam penelitian ini adalah analisis teks, yaitu dengan cara membaca novel yang akan diteliti secara cermat.

\section{PEMBAHASAN}

Pada bab ini diuraikan deskripsi latar dalam novel Hujan karya Tere 
Liye dan kelayakannya sebagai alternatif bahan ajar sastra di Sekolah Menengah Atas (SMA). Deskripsi latar yang ditemukan dan dikemukakan dalam bab ini terkait dengan ketiga jenis latar yaitu (1) latar tempat, (2) latar waktu, (3) latar sosial, dan menggunakan tiga pendekatan dalam deskripsi. Ketiga pendekatan dalam deskripsi tersebut, yaitu (1) pendekatan realistis, (2) pendekatan impresionistis, dan (3) pendekatan menurut sikap penulis. Pengarang juga membutuhkan diksi dan kiasan dalam menggunakan pendekatan untuk memperkuat deskripsi latar yang diciptakannya. Diksi yang penulis teliti dalam deskripsi latar novel Hujan ini adalah denotasi dan konotasi, eufemisme, genetik dan spesifik, serta kiasan yang penulis teliti adalah simile dan personifikasi.

\section{Deskripsi Latar Tempat}

Deskripsi latar tempat pada novel

Hujan karya Tere Liye dalam penelitian ini ditemukan berjumlah 17 data, 7 data menggunakan pendekatan realistis, 6 data menggunakan pendekatan impresionistis, dan 4 data menggunakan pendekatan menurut sikap penulis.

\section{a. Pendekatan Realistis}

Deskripsi latar tempat yang ditemukan dalam novel Hujan karya Tere Liye menggunakan pendekatan realistis sebab penulis mendeskripsikan latar sesuai dengan keadaan yang nyata, perincian deskripsi latarnya pun dipaparkan sedemikian rupa sehingga tampak seperti dipotret. Deskripsi latar tempat yang menggunakan pendekatan ini, yaitu deskripsi taman kota yang ada air mancurnya, kursi, taman, burungburung, serta ada turisnya pula.

\section{Personifikasi}

Data di bawah ini mendeskripsikan latar tempat, yaitu panti sosial.
Pengarang mendeskripsikan latar panti sosial ini dengan letaknya yang tidak jauh dari kolam air mancur, satu gedung setinggi enam lantai berwarna biru, simetris dengan jendelajendelanya, halaman yang luas dengan rumput yang dipotong rapi, serta pohon palem yang berbaris. Berikut data penelitian yang mendeskripsikan latar tempat tersebut.

"Letak panti sosial itu tidak jauh dari kolam air mancur. Kota mereka menyusut tinggal tiga puluh persen dari luas sebelumnya. Bangunan baru dibangun di sekitar Central Park. Lail sudah sering melintasinya saat panti sosial masih dibangun. Ada satu gedung setinggi enam lantai berwarna biru, simetris dengan jendelajendelanya. Halaman gedung itu luas dengan rumput terpotong rapi.

\section{Pohon-pohon palem berbaris.}

Panti sosial terlihat menyenangkan."

(H/LT/PR/KP/H76)

Berdasarkan data di atas, deskripsi latar tempat menggunakan kiasan berupa personifikasi.Penggunaan personifikasi pada data di atas terdapat pada kalimat Pohon-pohon palem berbaris. Pengarang menggunakan kata pohon palem yang digambarkan bertidak seperti manusia yaitu berbaris. Kata berbaris digunakan untuk gerakan manusia yang melakukan aktivitas seperti baris-berbaris. Kemudian, data ini digolongkan ke dalam kategori non alam dengan subkategorinya yaitu keadaan.

\section{b. Pendekatan Impresionistis}

Deskripsi latar tempat yang ditemukan dalam novel Hujan karya Tere Liye menggunakan pendekatan impresionistis sebab penulis mendeskripsikan latar bertolak dari kenyataan (realitas). Deskripsi latar 
tempat yang menggunakan pendekatan ini, yaitu deskripsi teknologi furnitur yang canggih.

\section{Genetik dan Spesifik}

Data di bawah ini mendeskripsikan latar tempat, yaitu asrama sekolah keperawatan. Pengarang mendeskripsikan latar ini dengankamar yang luas, dua tempat tidur terpisah, lemari, meja belajar yang ditanam di dinding dan lantai. Berikut data penelitian yang mendeskripsikan latar tempat tersebut.

"Lail dan Maryam juga menyukai asrama sekolah. Mereka tetap sekamar, dengan kamar yang lebih luas dibandingkan panti sosial. Ada dua tempat tidur terpisah, lemari, dan meja belajar yang ditanam di dinding dan lantai. Cukup mengetuk tombol di layar tablet untuk mengeluarkannya. Teknologi furnitur, peralatan rumah tangga, juga tidak ketinggalan. Ruangan yang terlihat kosong kemungkinan memiliki perabotan superlengkap ketika diaktifkan." (H/LT/PI/DGS/H190191).

Berdasarkan data di atas, deskripsi latar tempat menggunakan diksi berupa genetik dan spesifik. Penggunaan genetik dan spesifik pada data ini terdapat pada kata peralatan rumah tangga dan kalimat Ada dua tempat tidur terpisah, lemari, dan meja belajar yang ditanam di dinding dan lantai. Pada data tersebut, pengarang memilih kata peralatan rumah tanggasebagai kata genetik yang maknanya alat-alat yang digunakan atau perabotan rumah tangga, dan tempat tidur, lemari, dan meja belajar sebagai kata spesifik yang merupakan rincian dari jenis-jenis perabotan tersebut. Kemudian, data ini digolongkan ke dalam kategori non alam dengan subkategorinya yaitu keadaan.

\section{c. Pendekatan Menurut Sikap Penulis \\ Deskripsi latar tempat yang} ditemukan dalam novel Hujan karya Tere Liye menggunakan pendekatan menurut sikap penulis sebab penulis mengambil sikap bersungguh-sungguh dan ironis pada deskripsi yang ditulisnya. Deskripsi latar tempat yang menggunakan pendekatan ini, yaitu sikap ironis saat mendeskripsikan latar tempat kota pengungsian itu yang pemandangannya terlihat menyedihkan.

\section{Personifikasi}

Data di bawah ini menggunakan latar tempat, yaitu padang rumput yang menjadi lokasi pengungsian. Pengarang mendeskripsikan latar tempat ini dengan kota yang ada di tengah padang rumput, namun gempa menghancurkan seluruh kota, infrastuktur kota hancur, jalanan rusak, jaringan komunikasi terbatas, dan padang rumput berganti salju. Berikut ini data penelitian yang mendeskripsikan latar tempat tersebut.

"Saat melangkah keluar tenda, pemandangan menyedihkan terlihat. Kota itu ada di tengah padang rumput. Sebelum gempa enam tahun lalu, kota itu pusat peternakan terbesar. Puluhan ribu sapi digembalakan di padang rumput. Ratusan ribu ton daging segar dan jutaan liter susu dikirim ke seluruh negeri dari kota itu.

Gempa bumi menghancurkan seluruh kota, perubahan iklim menghabisi padang rumput.

Tidak ada yang tersisa. Infrasturktur kota hancur, jalanan rusak, jaringan komunikasi terbatas, kadang sinyalnya ada, lebih sering hilang..."

(H/LT/PSP/KP/H 208)

Berdasarkan data di atas, deskripsi latar tempat menggunakan kiasan berupa personifikasi. Pada data di atas 
terdapat bahasa kiasan berupa personifikasi yang terdapat pada kalimat Gempa bumi menghancurkan seluruh kota, perubahan iklim menghabisi padang rumput. Pengarang menggunakan kata gempa bumi dan iklim yang digambarkan bertidak seperti manusia yaitu menghancurkan dan menghabisi. Kata tersebut digunakan untuk tindakan manusia yang melakukan aktivitas. Kemudian, data ini digolongkan ke dalam kategori alam dengan subkategorinya yaitu lokasi.

\section{Deskripsi Latar Waktu}

Deskripsi latar waktu pada novel Hujan karya Tere Liye dalam penelitian ini ditemukan berjumlah 12 data, 3 data menggunakan pendekatan realistis, 3 data menggunakan pendekatan impresionistis, dan 6 data menggunakan pendekatan menurut sikap penulis.

\section{a. Pendekatan Realistis}

Deskripsi latar waktu yang ditemukan dalam novel Hujan karya Tere Liye menggunakan pendekatan realistis sebab penulis mendeskripsikan latar sesuai dengan keadaan yang nyata, perincian deskripsi latarnya pun dipaparkan sedemikian rupa sehingga tampak seperti dipotret. Deskripsi latar waktu yang menggunakan pendekatan ini, yaitu deskripsi sore hari yang cahaya matahari sudah mulai memudar, dan toko-toko mulai ditutup.

\section{Eufemisme}

Data deskripsi latar waktu yang menggunakan diksi berupa makna eufemisme, yaitu deskripsi sore hari. Pengarang mendeskripsikan latar ini dengan mataharinya yang mulai tumbang, dan meski sudah sore namun kolam air mancur justru semakin ramai oleh pengunjung.
"Matahari mulai tumbang di langit. Kolam air mancur semakin ramai oleh pengunjung yang menunggu malam hari, saat cahaya lampu membuat kolam air terlihat semakin menawan. 'Kita harus pulang, Lail. Besok jadwal keretaku pagi sekali, pukul enam. Aku hanya bisa berlibur sehari.' Lail menggangguk. Itu sudah lebih dari cukup. 'Mari kuantar kamu pulang ke panti." (H/LW/PR/DE/H 133)

Berdasarkan data di atas, deskripsi latar waktu menggunakan diksi berupa eufemisme. Penggunaan eufemisme pada data di atas terdapat pada kalimat Matahari mulai tumbang di langit. Pada kalimat tersebut, pengarang memilihc kata tumbang dianggap lebih tepat digunakan dibandingkan dengan istilah lainnya seperti tenggelam. Kemudian, data ini digolongkan ke dalam kategori alam dengan subkategorinya yaitu objek.

\section{b. Pendekatan Impresionistis}

Deskripsi latar waktu yang ditemukan dalam novel Hujan karya Tere Liye menggunakan pendekatan impresionistis sebab penulis mendeskripsikan latar bertolak dari kenyataan (realitas). Deskripsi latar waktu yang menggunakan pendekatan ini, yaitu deskripsi bertolak dengan kenyataan sesungguhnya yang belum adanya mobil listrik.

\section{Genetik dan Spesifik}

Data deskripsi latar waktu yang menggunakan diksi berupa makna genetik dan spesifik, yaitu deskripsi hari ke-70 setelah gempa. Pengarang mendeskripsikan latar waktu ini dengan kendaraan yang sudah banyak melintas di jalanan kota, abu langit sudah tidak ada, gerimis membungkus kota, rumput dan pohon kembali hijau. Berikut data 
penelitian yang mendeskripsikan latar waktu tersebut.

"Hari ke-70, kendaraan sudah banyak melintas di jalanan kota.

Mobil-mobil tenaga listrik sudah bisa digunakan. Transportasi berangsur pulih. Kereta tenaga diesel jarak pendek, sepanjang rel keretanya tidak hancur, sudah bisa melintas. Juga kapal-kapal laut, sudah kembali beroperasi. Itu penting sekali untuk mendistribusikan makanan ke kota-kota dan negara-negara yang terisolasi penuh. Beberapa penerbangan dengan rute tertentu juga sudah pulih. Abu di langit sudah nihil, penerbangan aman, sepanjang tidak menyentuh lapisan stratosfer..." (H/LW/PI/DGS/H69)

Berdasarkan data di atas, deskripsi latar waktu menggunakan diksi berupa genetik dan spesifik. Penggunaan genetik dan spesifik pada data ini terdapat pada kata-katatransportasi, mobil-mobil tenaga listrik, kereta tenaga diesel, dan kapal-kapal laut. Pada data tersebut, pengarang memilih kata transportasi sebagai kata genetik yang maknanya kendaraan pengangkut barang yang berpindah dari satu tempat ke tempat lain, dan mobil-mobil tenaga listrik, kereta tenaga diesel, kapalkapal laut sebagai kata spesifik yang merupakan rincian dari jenis-jenis transportasi tersebut. Kemudian, data ini digolongkan ke dalam kategori non alam dengan subkategorinya yaitu keadaan.

\section{c. Pendekatan Menurut Sikap Penulis}

Deskripsi latar waktu yang ditemukan dalam novel Hujan karya Tere Liye menggunakan pendekatan menurut sikap penulis sebab penulis mengambil sikap bersungguh-sungguh dan ironis pada deskripsi yang ditulisnya. Deskripsi latar waktu yang menggunakan pendekatan ini, yaitu deskripsi sikap cermat saat mendeskripsikan catatan sejarah letusan Gunung Toba sebagai perbandingan dari letusan gunung yang ada dalam cerita ini.

\section{Personifikasi}

Data di bawah ini mendeskripsikann latar waktu, yaitu malam hari.

Pengarang mendeskripsikan latar waktu ini dengan suhu bumi yang mulai turun drastis hingga lima sampai enam derajar Celsius, udara terasa menusuk tulang meski telah memakai selimut dan tenda ditutup rapat. Berikut ini data penelitian yang mendeskripsikan latar waktu tersebut.

"Malam itu suhu bumi mulai turun drastis, lima sampai enam derajat Celsius. Meski dengan selimut di dalam tenda tertutup rapat, udara tetap dingin menusuk tulang. Letusan gunung menyemburkan miliaran material ke angkasa. Sebagian besar material itu, seperti abu dan partikel berat lainnya, luruh ke bumi, sebagian lagi tidak. Saat Gunung Toba meletus 73.000 tahun lalu, ada enam miliar ton emisi gas sulfur dioksida yang masuk lapisan stratosfer. Gas itu menghalangi cahaya matahari yang menghyangatkan bumi, membuat suhu rata-rata permukaan bumi turun drastis hingga lima belas derajat Celsius selama sepuluh tahun, yang baru berangsur normal ratusan tahun berikutnya. Itulah yang disebut masa vorcanic winter. (H/LW/PSP/KP/H48-49)

Berdasarkan data di atas, deskripsi latar waktu menggunakan kiasan berupa personifikasi. Pada data di atas terdapat bahasa kiasan berupa personifikasi yang terdapat pada kalimat udara tetap dingin menusuk tulang. Pengarang menggunakan kata 
udara dingin digambarkan bertidak seperti manusia yaitu menusuk. Kata tersebutdigunakan untuk tindakan manusia yang melakukan perbuatan. Udara dingin yang merupakan benda mati yang diibaratkan seolah hidup seperti manusia hingga dapat menusuk. Kemudian, data ini digolongkan ke dalam kategori alam dengan subkategorinya yaitu objek.

\section{Deskripsi Latar Sosial}

Deskripsi latar sosial pada novel

Hujan karya Tere Liye dalam penelitian ini ditemukan berjumlah 9 data, 2 data menggunakan pendekatan realistis, 2 data menggunakan pendekatan impresionistis, dan 5 data menggunakan pendekatan menurut sikap penulis.

\section{a. Pendekatan Realistis}

Deskripsi latar sosial yang ditemukan dalam novel Hujan karya Tere Liye menggunakan pendekatan realistis sebab penulis mendeskripsikan latar sesuai dengan keadaan yang nyata, perincian deskripsi latarnya pun dipaparkan sedemikian rupa sehingga tampak seperti dipotret. Deskripsi latar sosial yang menggunakan pendekatan ini, yaitu deskripsi kehidupan di panti sosial yang harus dimulai dari pagi, disiplin.

\section{Denotasi dan Konotasi}

Deskripsi latar sosial yang ditemukan pada data ini yaitu deskripsi kehidupan di panti sosial. Pengarang mendeskripsikan latar ini dengan aktivitas yang dimulai pukul lima pagi dengan merapikan kamar masingmasing, anak yang bertugas mengepel lantai dan menyikat kamar mandi, anak-anak yang piket di dapur dan ruang makan harus bangun tiga puluh menit lebih awal dari anak-anak yang lain.

"Kehidupan di panti dimulai pukul lima pagi. Semua penghuni harus bangun, merapikan kamar masingmasing. Anak-anak yang bertugas mengepel lantai dan menyikat kamar mandi bangun tiga puluh menit lebih awal. Juga anak-anak yang mendapat piket bekerja di dapur dan ruang makan. Walaupun selama di tenda pengungsian punya rekor bangun kesiangan, Lail bisa bangun tepat waktu di panti karena Maryam selalu membangunkannya."

(H/LS/PR/DDK/H80)

Berdasarkan data di atas, deskripsi latar sosial menggunakan diksi berupa denotasi dan konotasi. Penggunaan denotasi pada data di atas terdapat pada kalimat Walaupun selama di tenda pengungsian punya rekor bangun kesiangan, Lail bisa bangun tepat waktu di panti karena Maryam selalu membangunkannya. Pada kalimat tersebut, pengarang mendeskripsikan bahwa tokoh yang bernama Lail yang biasanya bangun kesiangan jadi bisa bangun tepat waktu di panti sosial. Kata yang mengandung makna denotasi pada kalimat tersebut yaitu kata tepat waktu. Kata tepat waktu pada kalimat tersebut merupakan kata kerja yang menyatakan suatu perbuatan. Makna kata tersebut sesuai dengan makna konseptual. Penggunaan denotasi pada data ini secara langsung memperkuat pendekatan realistis dalam deskripsi yang diciptakan oleh pengarang. Makna konotasi pada kata rekor yang terdapat pada kalimat yang sama. Kata rekordipilih karena memiliki makna konseptual yaitu hasil terbaik, terbanyak. Tetapi pada kalimat tersebut, kata rekor memiliki makna kebiasaan bangun siang. Kemudian, data ini digolongkan ke dalam kategori non alam dengan subkategorinya yaitu rutinitas. 


\section{b. Pendekatan Impresionistis}

Deskripsi latar sosial yang

ditemukan dalam novel Hujan karya

Tere Liye menggunakan pendekatan

impresionistis sebab penulis

mendeskripsikan latar bertolak dari

kenyataan (realitas). Deskripsi latar

sosial yang menggunakan pendekatan

ini, yaitu deskripsi yang bertolak

belakang dengan kenyataan

sesungguhnya yang belum ada jam

tangan konvensional sevanggih itu

yang dapat melakukan banyak hal

dengan sekali ketuk saja.

\section{Personifikasi}

Pada pendekatan impresionistis ini terdapat 1 data deskripsi latar sosial yang menggunakan kiasan berupa personifikasi, yaitu deskripsi teknologi. Pengarang mendeskripsikan latar waktu ini dengan pekerja di perusahaan teknologi informasi lebih dulu terbiasa menggunakan jam tangan konvensional yang bisa melakukan banyak hal, dibandingkan dengan penduduk kota lain yang belum terbiasa menggunakannya.

"Aduh, sepertinya kereta juga terlambat pagi ini.' Ibunya memeriksa lengannya. Tidak ada jam tangan konvensional, melainkan layar sentuh berukuran kecil, yang menunjukkan pukul 07.46. Itu peranti model terbaru. Ukurannya $2 \times 3$ sentimeter, ditanam di lengan. Tinggal menggoyangkan lengan, layar itu menyala. Masih banyak penduduk kota yang belum terbiasa. Tapi karena bekerja di perusahaan teknologi informasi, ibu Lail telah menggunakan sejak enam bulan lalu. Sangat praktis. Layar itu bisa melakukan banyak hal."

(H/LS/PI/KP/H12)

Berdasarkan data di atas, deskripsi latar sosial menggunakan kiasan berupa personifikasi. Pada data di atas terdapat bahasa kiasan berupa personifikasi yang terdapat pada kalimat Layar itu bisa melakukan banyak hal. Pengarang menggunakan kata layar yang digambarkan bertidak seperti manusia yaitu melakukan banyak hal. Kata tersebutdigunakan untuk tindakan manusia yang melakukan aktivitas. Kemudian, data ini digolongkan ke dalam kategori non alam dengan subkategorinya yaitu keadaan.

\section{c. Pendekatan Menurut Sikap Penulis}

Deskripsi latar sosial yang ditemukan dalam novel Hujan karya Tere Liye menggunakan pendekatan menurut sikap penulis sebab penulis mengambil sikap bersungguh-sungguh dan ironis pada deskripsi yang ditulisnya. Deskripsi latar sosial yang menggunakan pendekatan ini, yaitu deskripsi skiap bersungguh-sungguh saat mendeskripsikan kondisi sosial keluarga tokoh Esok.

\section{Eufemisme}

Pengarang mendeskripsikan latar sosial ini dengan ayahnya yang meninggal sejak Esok usia dua tahun, empat kakaknya laki-laki semua, diantaranya kembar, dan Esok yang bungsu, mereka lima saudara mandiri, dan ibunya membuka toko kue. Berikut ini data penelitian yang mendeskripsikan latar waktu tersebut.

"Esok adalah anak bungsu dari lima bersaudara (dua di antaranya kembar). Empat kakaknya laki-laki dan dia sehari-hari terbiasa menghadapi sibling rivaly. Membuatnya matang lebih cepat. Ayahnya meninggal saat Esok masih dua tahun. Sejak saat itu mereka lima bersaudara harus mandiri. Ibunya sibuk bekerja, membuka toko kue di rumah-tempat yang mereka tuju 
satu jam kemudian."

(H/LS/PSP/DE/H36)

Berdasarkan data di atas, deskripsi latar sosial menggunakan diksi berupa eufemisme. Penggunaan eufemisme pada data di atas terdapat pada kalimat Ayahnya meninggal saat Esok masih dua tahun. Pada kalimat tersebut, pengarang memilih kata meninggal dalam mendeskripsikan kondisi sosial keluarga Esok. Kata meninggal yang dianggap lebih halus maknanya dan lebih tepat digunakan dibandingkan dengan istilah lainnya seperti mati. Kemudian, data ini digolongkan ke dalam kategori non alam dengan subkategorinya yaitu keadaan.

\section{Rancangan Pembelajaran$$
\text { a. Identitas Mata Pelajaran }
$$$$
\text { Satuan Pendidikan : SMA }
$$$$
\text { Mata Pelajaran : B. Indonesia }
$$$$
\text { Kelas/Semester : XII/Dua }
$$$$
\text { Materi Pokok : Menganalisis Isi }
$$$$
\text { dan Kebahasaan }
$$$$
\text { Novel }
$$ \\ Alokasi Waktu : 2 x 45 menit}

\section{b. Kompetesi Inti}

Kompetensi inti (KI) berfungsi sebagai unsur pengorganisasi bagi kompetensi dasar (KD). Kompetensi inti yang sesuai dengan materi yang akan diajarkan ialah KI 3 (Memahami pengetahuan (faktual, konseptual, dan prosedural) berdasarkan rasa ingin tahunya tentang ilmu pengetahuan, teknologi, seni, budaya terkait fenomena dan kejadian tampak mata). Pada KI tersebut, siswa akan dapat mengetahui unsur-unsur pembangun novel, khususnya deskripsi latar.

\section{c. Kompetensi Dasar dan Indikator}

Kompetensi dasar yang sesuai dengan pembelajaran menganalisis teks novelyang mencangkup keempat aspek kompetensi inti adalah sebagai berikut.

3.9 Menganalisis isi dan kebahasaan novel.

3.9.1 Menemukan unsur-unsur pembangun novel.

3.9.2 Menemukan struktur dan aspek kebahasaan novel.

3.9.3 Menyimpulkan unsur-unsur pembangun karya sastra dengan bukti yang mendukung dan novel yang dibaca atau didengar.

\section{d. Tujuan Pembelajaran}

Tujuan pembelajaran adalah untuk mencapai kompetensi dasar berdasarkan indikator yang dibuat. Tujuan pada pembelajaran kali ini adalah setelah siswa membaca deskripsi latar dengan tiga pendekatannya, siswa mampu menganalisis deskripsi latar dengan benar.

\section{e. Materi Pembelajaran}

Adapun materi pembelajaran yang akan disesuaikan dengan tujuan pembelajaran, karakteristik peserta didik, dan alokasi waktu sebagai berikut.

1. Kutipan novel Hujan.

2. Unsur intrinsik pada novel.

3. Jenis-jenis latar dan pendekatan deskripsinya dalam cuplikan novel Hujan.

\section{f. Alokasi Waktu}

Untuk siswa tingkat Sekolah Menengah Atas (SMA) kelas XII pembelajaran dilakukan selama2x45 menit. Alokasi waktu tersebut digunakan guru untuk membelajarkan materi menganalisis teks deskripsi latar novel selama $2 \times 45$ menit dalam proses pembelajaran. Materi menganalisis teks deskripsi latar novel dengan KD 3.9 dilaksanakan selama 2x45 menit sesuai dengan pembelajaran tingkat SMA dan 
dilakukan sebanyak satu kali tatap muka atau pertemuan.

\section{g. Model Pembelajaran}

Model pembelajaran yang digunakan yaitu discovery learning. Dengan model discovery learning peserta didik akan menemukan latar yang termasuk dalam materi pembelajaran memproduksi teks deskripsi latar novel. Langkah pembelajarannya adalah sebagai berikut. Tujuan penggunaan model pembelajaran discovery learning adalah dengan pembelajaran tersebut siswa dapat lebih memahami dan mampu menganalisis unsur intrinsik khususnya latar dengan mudah.

\section{h. Media dan Sumber Belajar}

Penjabaran media pembelajaran dalam rancangan pelaksanaan

pembelajaranadalah sebagai berikut.

1) Media pembelajaran: Power point materi teks novel yang mencangkuppengertian latar, pengertian deskripsi, dan contoh teks deskripsi latardalam novel Hujankarya Tere Liye.

2) Penggunaan media pembelajaran power point dapat ditunjang denganmedia lain seperti printout teks novel Hujankarya Tere Liye.

3) Sumber Belajar

a. Buku referensi lain yang berkaitan dengan materi pembelajaran teks novel.

b. Buku referensi yang berkaitan dengan teori deskripsi latar dan pendekatannya.

\section{i. Kegiatan Pembelajaran}

Kegiatan pembelajaran yang dilakukan guru dan peserta didik untuk materi menganalisis novel dengan memperhatikan isi dan kebahasaannya adalah sebagai berikut.

1) Kegiatan Awal
Guru memasuki ruang kelas, mengucap salam dan menyapa siswa. Sebelum memulai pelajaran, guru mengabsen siswa untuk mengetahui siswa yang tidak hadir. Setelah itu, guru memberi informasi tujuan pembelajaranyang akan dicapai, yaitu siswa mampu menganalisis dan merancang novel dengan memperhatikan isi dan kebahasaannya. Kemudian, guru membagi siswa menjadi beberapa kelompok. Setelah guru membagi kelompok, guru mengatur posisi duduk siswa sesuai dengan kelompoknya masing-masing.

2) Kegiatan Inti

Langkah pembelajaran dalam kegiatan inti adalah langkah pembelajaran pendekatan saintifik yang meliputi kegiatan mengamati, menanya, mencoba, mengasosiasi, dan mengomunikasikan.

3) Kegiatan Penutup

Kegiatan akhir pembelajaran, yaitu refleksi dan tindak lanjut. Kegiatan refleksi, guru dan siswa mengingat kembali dan mengulas pelajaran disertai dengan penjelasan dari guru.

\section{j. Penilaian}

Di akhir kegiatan pembelajaran (penutup), guru akan melakukan penilaian kepada siswa. Nilai hasil belajar siswa didapatkan dengan melakukan pengamatan (observasi) dan penilaian terhadap 3 aspek, yaitu aspek sikap, aspek pengetahuan, dan aspek keterampilan.

\section{SIMPULAN DAN SARAN Simpulan}

Berdasarkan hasil analisis novel Ayah karya Andrea Hirata, peneliti mengambil simpulan sebagai berikut.

1. Temuan data deskripsi latar tempat pada novel Hujan lebih dominan pada pendekatan realistis dengan diksi yang ditemukan yaitu denotasi 
konotasi, dan eufemisme, serta kiasan yang ditemukan yaitu simile dan personifikasi.

2. Temuan data deskripsi latar waktu pada novel Hujan lebih dominan pada pendekatan menurut sikap penulis dengan diksi yang ditemukan yaitu denotasi konotasi, dan eufemisme, serta kiasan yang ditemukan yaitu personifikasi.

3. Temuan data deskripsi latar sosial pada novel Hujan lebih dominan pada pendekatan menurut sikap penulis dengan diksi yang ditemukan yaitu eufemisme, dan genetik spesifik, serta kiasan yang ditemukan yaitu personifikasi.

4. Hasil penelitian deskripsi latar dalam kumpulan novel Hujan karya Tere Liye dapat dirancang sebagai pembelajaran sastra di SMA sesuai dengan KD 3 .9 Menganalisis isi dan kebahasaan novel. Rancangan pembelajaran ini menggunakan model pembelajaran discovery learning, dengan alokasi waktu 2 jam pelajaran $1 \mathrm{x}$ pertemuan, dan media yang digunakan yaitu power point materi deskripsi latar dalam novel, dan novel Hujan karya Tere Liye. Rancangan pembelajaran ini dapat digunakan pada siswa kelas XII semester genap.

\section{Saran}

Berdasarkan hasil analisis terhadap novel Hujan karya Tere Liye, peneliti menyarankan sebagai berikut.

1. Bagi pembaca umum yang ingin mengadakan penelitian dengan kajian yang serupa sebaiknya dapat memilih novel lain agar dapat dijadikan referensi yang lebih variatif dan tentunya harus disesuaikan dengan perkembangan kurikulum yang berlaku di sekolah.

2. Guru bidang studi mata pelajaran Bahasa Indonesia dapat menggunakan rancangan pembelajaran yang ada pada penelitian ini dalam pembelajaran menganalisis isi dan kebahasaan novel.

\section{DAFTAR PUSTAKA}

Angraeni, Ria. 2014. Deskripsi Latar dan Fungsinya dalam Novel Cinta di dalam Gelas dan Implikasinya. Bandar Lampung: Jurnal Kata Universitas Lampung.

Emzir dan Rohman, Saifur. 2016. Teori dan Pengajaran Sastra. Jakarta: Rajawali Pers.

Keraf, Gorys. 1982. Eksposisi dan Deskripsi. Jakarta: PT Gramedia Pustaka Utama.

Moleong, Lexy. 2005. Metodologi Penelitian Kualitatif. Bandung: Remaja Rosdakarya Offset.

Nurgiyantoro, Burhan. 2015. Teori Pengkajian Fiksi. Yogyakarta: Gadjah Mada University Press.

Priyatni, Endah Tri. 2010. Membaca Sastra dengan Ancangan Literasi Kritis. Jakarta: Bumi Aksara.

Tere Liye. 2017. Hujan. Jakarta: Gramedia Pustaka Utama.

Uno, Hamzah B. 2008. Perencanaan Pembelajaran. Jakarta: Sinar Grafika Offset.

Wiyatmi. 2008. Pengantar Kajian Sastra. Yogyakarta: Pustaka.

Wulandari, Shinta. 2018. Keberfungsian Latar dalam Novel Pingkan Melipat Jarak Karya Sapardi Djoko Damono dan Rancangan Pembelajarannya di SMA. Bandar Lampung: Jurnal Kata Universitas Lampung. 